\title{
Seasonal Variations and Anatomical Distribution of Alginic Acid in Sargassum Spp. Found Along the Coasts of Puerto Rico'
}

\author{
Nilda E. Aponte de Otaola ${ }^{2}$, Manuel Díaz-Piferrer ${ }^{3}$ and \\ Horace D. Graham ${ }^{4}$
}

\begin{abstract}
Four species of Sargassum were analyzed for their content of alginic acid at the different seasons of the year. S. polyceratium and S. vulgare, two sessile species, had maximum amounts of alginic acid at the vegetative stage and peak reproductive phase in May. Minimum amounts were detected in the postreproductive phase. The whole plants had an average of $20.3 \%$ and $17.9 \%$ alginic acid for S. polyceratium and S. vulgare, respectively. In both species, the stipes had more alginic acid than the fronds. Whole plants of the pelagic species yielded an average of $18.8 \%$ and $19.9 \%$ alginic acid, for S. fluitans and S. natans, respectively. Stipes of S. fluitans had more alginic acid than the fronds, whereas in S. natans, the situation was reversed.
\end{abstract}

\section{INTRODUCTION}

One of the most important polysaccharides obtained from algae is alginic acid (14). It is a major constituent of the cell walls of Phaeophyta (10), located mainly in the middle lamella and in the primary wall $(1,18$, 19). According to Baardseth (2), alginates occur both in the intercellular region and the cell wall and their biological functions are considered primarily of structural and ion exchange type.

Alginic acid is a complex polyuronide which is quite stable to hydrolysis. It is comprised mainly of $\beta-1-4$, linked D-mannuronic acid and Lguluronic acid units. It is insoluble in water. Its $\mathrm{Na}, \mathrm{K}, \mathrm{NH}_{4}, \mathrm{Mg}$, and $\mathrm{Fe}$ (ferrous) salts are soluble in water giving high viscosities, whereas $\mathrm{Ca}$, $\mathrm{Al}, \mathrm{Zn}, \mathrm{Cu}, \mathrm{Cr}, \mathrm{Fe}$ (ferric) and $\mathrm{Ag}$ complexes yield insoluble compounds $(12,13,14)$. The soluble salts of this polymer, especially the sodium salt, are generally referred to as algins. Any salt of the polymer is an alginate while the organic salts or esters are called algin derivatives (22).

The most widely used compound is the soluble sodium alginate. In many applications sodium alginate is converted to the insoluble calcium salt to form gels or films. Among the esters prepared from alginic acid, the most important is the propylene glycol ester, which has found great use in the food industry as a thickener for low acid foods.

\footnotetext{
${ }^{1}$ Manuscript submitted to Editorial Board August 30, 1982.

${ }^{2}$ Former student, Department of Marine Sciences, University of Puerto Rico, Mayagüez, Puerto Rico.

${ }^{3}$ Professor, Department of Marine Sciences, University of Puerto Rico, Mayagüez, Puerto Rico.

${ }^{4}$ Professor, Department of Chemistry, University of Puerto Rico, Mayagüez, Puerto Rico.
} 
Because of the variety of properties of the different salts of alginic acid, they have a remarkably wide range of applications for industrial uses. In the food, textile, pharmaceutical, paper and other industries they act as thickening, suspending, stabilizing, emulsifiying, gel producing, or film forming agents without masking or adding flavors. These same properties make them useful as binding material for pills and tablets, in the production of cosmetics, paints and dairy products such as ice cream, cream cheese, pie fillings, puddings, toppings, icings, syrups and frozen fruits (4).

Macrocystis pyrifera, the giant kelp which grows in off shore waters of California, constitutes the world's largest single source of algin. Although alginic acid is found in all brown algae, only some species are being used as commercial sources (table 1). The algae commonly used for the

TABLE 1.-Botanical sources of commercial alginate

\begin{tabular}{ll}
\multicolumn{1}{c}{ Genus } & \multicolumn{1}{c}{ Species } \\
\hline Macrocystis & pyrifera (L.) C. Agardh \\
M. & integrifolia Bory \\
Laminaria & digitata (L.) Lamouroux \\
L. & cloustonii Edmonds \\
L. & saccharina (L.) Lamouroux \\
L. & stenophylla (Kützing) J. Agardh \\
Ascophyllum & nodosum (L.) Le Jolis \\
Nereocystis & luetheana (Mert.) Postels \& Ruprecht \\
Fucus & vesiculosus Linnaeus \\
F. & serratus Linnaeus \\
F. & spiralis Linnaeus \\
Ecklonia & cava Kjellman \\
E. & radiata (C. Agardh) J. Agardh \\
Pelvetia & canaliculata (L.) Decaisne \& Thuret \\
\hline
\end{tabular}

commercial extraction of alginic acid are not found in the tropics. Moreover, there are none similar in size to the kelps. However, there are a few genera of brown algae, for example, Sargassum, with species of moderate to relatively large size and with high population densities, which may be potential commercial sources of algin.

Even though the kelps thrive in deep waters, the plants are also found populating the rocky eulittoral zone. In a sense Sargassum in the tropics could be considered as an ecological equivalent of the kelps because species of Sargassum thrive in deep water as well as in the eulittoral zone,

Thirteen recognized species of sessile Sargassum are found in the western Atlantic ocean. They are: S. polyceratium Montagne, S. platycarpum Montagne, S. histrix J. Agardh, S. rigidulum Kützing, S. vulgare 
C. Agardh, S. pteropleuron Grunow, S. filipendula C. Agardh, S. acinarium (L.) C. Agardh, S. cymosum C. Agardh, S. ramifolium Kützing, S. bermudense Grunow, S. furcatum Kützing and $S$. wolfii Earle $(9,30)$. The first seven species listed above are found commonly along the Puerto Rican coasts and are fairly abundant on the rocky shores from the mideulittoral to the sublittoral zone to a depth of $25 \mathrm{~m}$ to $30 \mathrm{~m}$. Along the Puerto Rican coasts they follow a common pattern of distribution in which $S$. polyceratium, S. platycarpum, S. rigidulum or $S$. histrix are found in the middle and inferior fringe of the eulittoral zone. S. vulgare and $S$. pteropleuron are found commonly in the inferior fringe and lower down. S. filipendula is always submerged at a depth of 2 to $3 \mathrm{~m}$. Added to these, great masses of two pelagic species, S. fluitans Børgesen and S. natans (L.) J. Meyen arrive seasonally at the Antillean shoreline in varying quantities. In Puerto Rico, the largest arrivals of pelagic sargaza are observed from May to July with peak arrival in June. They may be seen in September according to the "Evangelina Collection" (private collection of M. Diaz-Piferrer). On the Cuban coasts the pelagic Sargassum arrives from June to August with peak arrival in July (7). These observations on the arrival of the weeds are in accordance with the changes in the surface currents in the Atlantic ocean and the Caribbean basin (31).

In view of the commercial importance of alginic acid it seems worthwhile to assess the content of this polysaccharide in algae found along the coasts of Puerto Rico, variations in the quantities at the different seasons of the year, and its distribution in the parts of the plants.

This article summarizes data obtained on the above-mentioned points. Such information is considered valuable because if alginate can be extracted from these algae on even a small commercial scale, it may be enough to satisfy local demands and will be a source of employment.

\section{MATERIALS AND METHODS}

Sargassum polyceratium plants were collected in an open bay at Punta Jagüey, El Faro, Cabo Rojo, which is the most southwestern point of the island of Puerto Rico. The area consists of an arid peninsula about two miles long surrounded by three bays: Bahía Sucia on the east, La Playuela on the south and Bahia Salinas on the west. The pelagic species, $S$. fluitans and $S$. natans were collected at Bahia Sucia, where they are heavily deposited in June. Sargassum vulgare plants were collected south of Punta Guanajibo, which is part of the Mayagüez beaches at the western part of the island. The mouth of the Guanajibo river is located north of Punta Guanajibo and Bahía Bramadero at the south. The sessile species were collected every other month. The pelagics were collected whenever 
they could be found. The hand-collected algae were carried to the laboratory in dark plastic bags filled with seawater to avoid dehydration and decomposition.

In the laboratory, the plants were separated according to their sexual stages, that is, reproductive and vegetative. They were washed with fresh water and the epiphytes were removed by hand. For each batch, 20 plants were picked at random and their length recorded. Some plants were left intact to determine the alginic acid content of whole plants while others were segregated into fronds and stipes to analyze each part separately. The whole plant and the parts were dried at $80^{\circ} \mathrm{C}$ for 10 to 16 hours. The dried material was ground finely in a hammer mill. The powder (150 mesh) was placed in closed amber glass bottles and stored at ambient temperature $\left(25\right.$ to $\left.26^{\circ} \mathrm{C}\right)$. For the extraction, the dried tissue $(20 \mathrm{~g}$ for whole plants and fronds, $10 \mathrm{~g}$ for stipes) was treated once with $200 \mathrm{ml}$ of $5 \% \mathrm{HCl}$. The mixture was centrifuged at $1,500 \mathrm{~g}$ for $10 \mathrm{~min}$. The supernatant was discarded and the residue extracted three times with $200 \mathrm{ml}$ of $4 \% \mathrm{Na}_{2} \mathrm{CO}_{3}$ at $60^{\circ} \mathrm{C}$ for $15 \mathrm{~min}$ with occasional stirring. The mixtures were centrifuged, the supernatant of the extractions pooled, and the residue washed twice with $700 \mathrm{ml}$ of distilled water each time. The supernatant of the extraction and the washings were treated separately with 90 to $120 \mathrm{ml}$ of $25 \% \mathrm{CaCl}_{2} \cdot 2 \mathrm{H}_{2} \mathrm{O}$ added with constant stirring until precipitation was completed. The calcium alginate obtained was washed twice with distilled water and filtered through three layers of cheesecloth, scraped off and dried in tared pans at $80^{\circ} \mathrm{C}$ for 10 to 12 hours. The dried calcium alginate was ground and stored in labeled plastic bags.

For the quantitative analysis of the alginic acid, $100 \mathrm{mg}$ of the calcium alginate (dry weight basis) was dissolved by gentle heating in $50 \mathrm{ml}$ of $1 \%$ sodium metaphosphate and then diluted to $250 \mathrm{ml}$ with distilled water. Quantitative analysis of the alginate was done with the ferricsulfuric reagent (11). One to $5 \mathrm{ml}$ of the calcium alginate suspensions was placed in $25 \times 200 \mathrm{~mm}$ borosilicate tubes (in duplicate) and dried for 10 to 16 hours at $100^{\circ} \mathrm{C}$. Tubes containing 1 to $5 \mathrm{ml}$ of $0.2 \%$ sodium metaphosphate, depending on the aliquot of calcium alginate suspension used, were included as reagent blanks. Five $\mathrm{ml}$ of the ferric-sulfuric reagent were added to each tube and the content mixed well by gentle shaking. The tubes and their contents were heated for $12 \mathrm{~min}$ at $60^{\circ} \mathrm{C}$. Timing began at the moment the tubes were placed in the bath. At the end of this period, the tubes were placed in a $29 \pm 1^{\circ} \mathrm{C}$ water bath for 90 min, after which the tubes were removed, and the color developed measured at $495 \mathrm{~nm}$ against a reagent blank.

The amount of alginate was determined from a reference curve which 
was prepared from stock dispersions containing $0,50,100,150,200,250$, $300,350,400,450$ and $500 \mu \mathrm{g}$ of sodium alginate per $\mathrm{ml}$ dispersed in $0.2 \%$ sodium metaphosphate. One $\mathrm{ml}$ of each dispersion was placed in $25 \times$ $200 \mathrm{~mm}$ borosilicate tubes and the content dried at $100^{\circ} \mathrm{C}$ for 10 to 16 hours. Then $5 \mathrm{ml}$ of the ferric-sulfuric reagent was added, the mixture

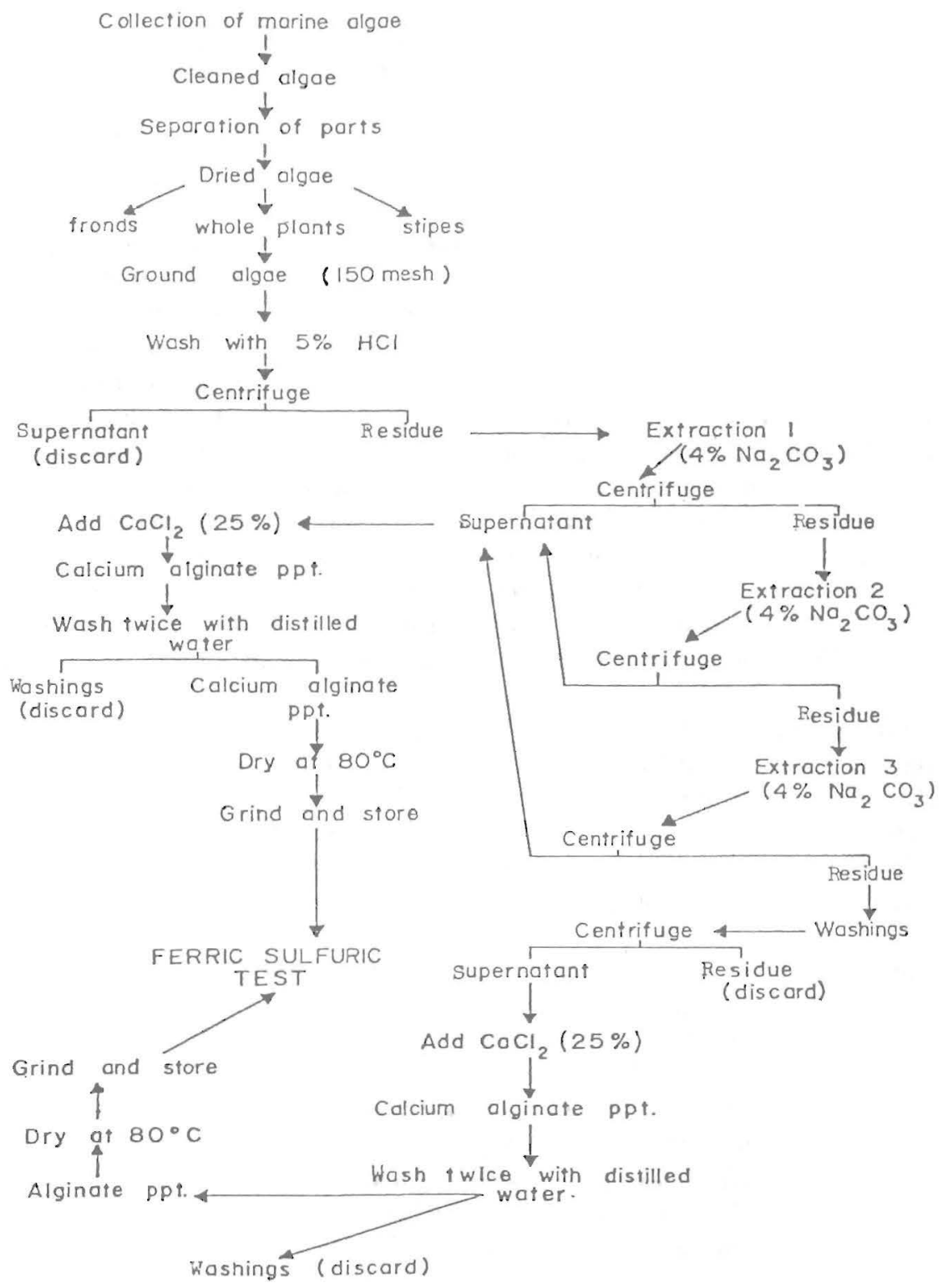

FIG. 1.-Flow sheet of extraction and analytical steps. 
heated for $12 \mathrm{~min}$ at $60^{\circ} \mathrm{C}$, aged for $90 \mathrm{~min}$ at $29 \pm 1^{\circ} \mathrm{C}$ and the density of the color measured at $495 \mathrm{~nm}$. A plot against the optical density versus the amount of added alginate produces a straight line. A flow sheet of all the manipulations is shown in figure 1.

\section{RESULTS AND DISCUSSION}

For both sessile species, the maximum levels of alginic acid were recorded in May coinciding in both cases with their vegetative stages and

TABLE 2.-Alginic acid levels in Sargassum vulgare C. Agardh with respect to reproductive stage and length of the plant

\begin{tabular}{lccrcr}
\hline $\begin{array}{c}\text { Date } \\
(1978)\end{array}$ & $\begin{array}{c}\text { Reproductive } \\
\text { stage }^{\mathrm{I}}\end{array}$ & $\begin{array}{c}\text { Mean } \\
\text { length (cm) } \\
(20 \text { plants) }\end{array}$ & \multicolumn{3}{c}{$\begin{array}{c}\text { Alginic acid } \\
(\% \text { D. W. basis })^{2}\end{array}$} \\
\hline January & $\mathrm{R}$ & 22.2 & $\begin{array}{c}\text { Whole } \\
\text { plant }\end{array}$ & Frond & Stipe \\
March & $\mathrm{R}$ & 27.5 & 1.7 & 7.4 & 11.4 \\
May & $\mathrm{V}$ & 17.5 & 25.1 & 15.5 & 22.7 \\
July & $\mathrm{R}$ & 24.2 & 22.7 & 24.5 & 29.2 \\
September & $\mathrm{R}$ & 23.8 & 19.5 & 23.4 & 28.3 \\
September & $\mathrm{V}$ & 13.2 & 16.6 & 18.5 & 23.5 \\
November & $\mathrm{R}$ & 32.2 & 17.3 & 16.5 & 23.5 \\
\hline
\end{tabular}

${ }^{1} \mathrm{R}=$ reproductive; $\mathrm{V}=$ vegetative.

${ }^{2}$ Mean of duplicate samples.

TABLE 3.-Alginic acid levels of Sargassum polyceratium Montagne with respect to reproductive stage and length of the plant

\begin{tabular}{lccccc}
\hline $\begin{array}{c}\text { Date } \\
(1978)\end{array}$ & $\begin{array}{c}\text { Reproductive } \\
\text { stage }^{1}\end{array}$ & $\begin{array}{c}\text { Mean } \\
\text { length (cm) } \\
(20 \text { plants })\end{array}$ & \multicolumn{3}{c}{$\begin{array}{c}\text { Alginic acid } \\
(\% \text { D. W. basis })^{2}\end{array}$} \\
\hline January & & & $\begin{array}{c}\text { Whole } \\
\text { plant }\end{array}$ & Frond & Stipe \\
March & $\mathrm{R}$ & 10.7 & 12.7 & 12.6 & 18.2 \\
May & $\mathrm{R}$ & 17.6 & 18.0 & 17.9 & 20.2 \\
May & $\mathrm{V}$ & 14.8 & 26.3 & 25.8 & 25.1 \\
July & $\mathrm{R}$ & 20.0 & 24.6 & 23.3 & 32.3 \\
September & $\mathrm{R}$ & 21.8 & 23.4 & 24.6 & 32.4 \\
November & $\mathrm{R}$ & 23.0 & 22.3 & 22.8 & 30.6 \\
\hline
\end{tabular}

${ }^{1} \mathrm{R}=$ reproductive; $\mathrm{V}$ = vegetative.

${ }^{2}$ Mean of duplicate samples.

their peak reproductive phases. The lowest values in alginic acid content were associated with old and decaying plants after the fruiting period (tables 2,3). The alginic acid content in S. polyceratium and S. vulgare varied in a very similar way with regard to their reproductive cycle. The relationship between the reproductive stage of Sargassum and its alginic acid content has been discussed by other workers $(5,23,27)$, and the 
results obtained in this investigation show similar trends. At maturity the alginic acid content of Sargassum is more constant or fairly variable at a lower level than at the peak level for the species. At the senescent stage of the plant the alginic acid level falls to a minimum. S. polyceratium and $S$. vulgare, at the reproductive stages, collected from July to November, showed a gradual decrease in their alginic acid content. This decrease can be attributed to the degenerated conditions of the plant after the fruiting period.

Higher values of alginic acid in the stipes than in the fronds in $S$. vulgare and S. polyceratium were noted (tables 2,3). Data obtained here indicate that in $S$. vulgare and $S$. polyceratium changes in the alginic acid levels followed a similar trend in all the parts. An increase in the alginic acid content of one part, the stipe, is associated with an increase in the alginic acid content of the other part, the frond. In S. polyceratium there was little difference in the alginic acid content of stipes and fronds of the plants in the vegetative stage, collected in May. A very similar situation was observed in the fully developed vegetative stage of plants of $S$. vulgare collected in May. In these plants, the alginic acid content prior to the reproductive stage is uniform throughout the body of the plant.

Other investigators $(24,25)$ have reported that in the sessile species the alginic acid content of the different parts of the weeds differs from species to species and varies according to age, sexual stage, and environmental factors affecting the plant. During the development of the plant, the alginic acid content of the whole plant increases during the growing period. This increase in the alginic acid content of the plant occurs more rapidly in the stipes than in the fronds. As the plant approaches full maturity, the alginic acid content of the whole plant is nearly uniform. At this point the fronds reach their maximum values as recorded in this investigation. After the fruiting period, the alginic acid content of the fronds and stipes decreases. This decrease in alginic acid occurs more rapidly in the fronds than in the stipes. As shown here, this is in agreement with the report of Rao (27) from his investigations in India.

Tide and changes in the water level can affect the content of alginic acid in eulittoral weeds since they control their periods of exposure and depth of immersion. Also, the rise and fall of the tides involve alterations in the light intensities that may affect the synthesis of alginic acid (15).

It has been proposed that the biological function of alginic acid in the plants is in the prevention of the excessive loss of water or desiccation of the plant (29). It has been proposed also that alginic acid helps the plant to meet the flexibility requirements of the intertidal environment of most Phaeophyta (10). 
The monthly average water level measured at the Magueyes hydrographic station at Parguera, Puerto Rico, shows that the lowest water levels occur from April to June, especially in May, and the higher water levels occur from September to November.

In $S$. polyceratium and $S$. vulgare the highest values of alginic acid were coincident with the lowest tides observed during the year (May) and the lowest values were recorded during the months of high water level.

The data presented support the belief that the biological function of alginates is the protection against desiccation, since high alginic acid levels were recorded in May when the plants were exposed for longer periods and low levels were recorded when the plants were submerged most of the time because of the high water levels.

These high alginic acid levels in S. polyceratium and S. vulgare are also associated, as stated before, with the peak mature phases of the life cycles

TABLE 4.-Alginic acid levels of Sargassum natans (L.) J. Meyen and Sargassum fluitans Børgesen

\begin{tabular}{lcccc}
\hline \multicolumn{1}{c}{ Plant } & Date & \multicolumn{3}{c}{$\begin{array}{c}\text { Alginic acid } \\
(\% \text { D. W. basis })^{1}\end{array}$} \\
\hline & & $\begin{array}{c}\text { Whole } \\
\text { plant }\end{array}$ & Frond & Stipe \\
S. natans & May 1978 & 19.9 & 23.4 & 19.7 \\
S. fluitans & May 1978 & 18.8 & 18.0 & 23.6 \\
\hline
\end{tabular}

${ }^{\mathrm{I}}$ Mean of duplicate samples.

of the plants. Also, there may be some relation between the sexual cycle of the weeds, the rise and fall of the water level and the alginic acid content of the plants. It has been stated that sexual reproduction in some eulittoral algae is affected by tides (16). Baker (3) concludes that the species growing at higher levels on the shore require longer periods of exposure for maximum liberation of sexual cells. Variations in the alginic acid content of the weeds, in his opinion, are probably the result of a series of concomitant internal and environmental factors.

The pelagic sargaza samples analyzed were collected in May and June soon after their arrival at the shore of Bahia Sucia, to ensure that the weeds were not affected by desiccation or bacterial decay.

The alginic acid content of the pelagic weeds is not affected by sexual cycles, tides or currents, since their reproduction is only vegetative (fragmentation) and they live in a floating state. The main factor affecting the alginic acid yields of these weeds is the condition of the plant at the moment of collection. They may be either fresh or decayed, depending on the time after arrival at the shore. 
In $S$. fluitans, as in the sessile species, the alginate content of the stipes $(23.6 \%)$ was higher than the alginate content of the fronds (18.0\%). Whole plants yielded $18.8 \%$. In S. natans the alginic acid level was found to be higher in the fronds (23.4\%) than in the stipes $(19.7 \%)$. Whole plants yielded $18.8 \%$ alginate (table 4 ).

Comparative values for alginic acid content of Sargassum in the Caribbean are shown in table 5 . The values range from $13 \%$ to $21 \%$ in the sessile species and from $6 \%$ to $20 \%$ in the pelagics. The alginic acid levels determined in this investigation are in agreement with the values reported in the literature.

This work shows that the Sargassum species off the coasts of Puerto

TABLE 5.-Alginic acid levels of Sargassum spp. from the Caribbean

\begin{tabular}{|c|c|c|c|c|c|}
\hline Species & Date & Locality & Habitat & \multicolumn{2}{|c|}{$\begin{array}{c}\text { Alginic acid } \\
(\% \text { D. W. basis) }\end{array}$} \\
\hline S. polyceratium & $11-1956(7)^{1}$ & Juraguá, Cuba & Near a river & 14.4 & \\
\hline S. polyceratium & $11-1956(7)$ & El Caney, Cuba & Exposed to surge & 20.0 & \\
\hline S. polyceratium & $2-1956(7)$ & Juraguá, Cuba & Near a river & 13.9 & \\
\hline S. polyceratium & $2-1957(7)$ & El Caney, Cuba & Exposed to surge & 15.8 & \\
\hline S. polyceratium & $7-?(8)$ & Puerto Rico & - & 21.0 & $12-24^{* 2}$ \\
\hline S. polyceratium & $2-?(8)$ & Puerto Rico & - & 17.9 & \\
\hline S. natans & $6-1956(7)$ & Siboney, Cuba & Floating & 16.0 & \\
\hline S. natans & $2-1957(7)$ & El Morro, Cuba & Floating & 15.2 & $18.8^{* 2}$ \\
\hline S. natans & $10-1952(28)$ & Habana, Cuba & Floating & $16-20$ & \\
\hline S. natans & $4-1949(6)$ & Florida & Floating & 9.0 & \\
\hline S. natans & $7-?(8)$ & Puerto Rico & Floating & 17.6 & $19.9^{* 2}$ \\
\hline S. fluitans & $6-1956(7)$ & Siboney, Cuba & Floating & 18.8 & \\
\hline S. fluitans & $2-1957(7)$ & El Morro, Cuba & Floating & 16.7 & \\
\hline S. fluitans & $2-1949(6)$ & Florida & Floating & 6.8 & \\
\hline S. fluitans & $7-?(8)$ & Puerto Rico & Floating & 18.5 & \\
\hline S. vulgare & 1978 & Mayagüez, P.R. & Rocks & - & $724^{* 2}$ \\
\hline
\end{tabular}

${ }^{1}$ Number in parentheses indicates corresponding reference.

$2 *$ Indicates data from the present study.

Rico have a good content of alginic acid comparable to values obtained for this species in other areas of the world (table 6). Commercial exploitation would depend on the quantity of the algae available annually and other economic factors. As far as can be ascertained, this constitutes the first data available on the distribution of alginate in the different parts of Sargassum in Puerto Rico, at different seasons and at different reproductive stages.

The test used in this investigation (ferric-sulfuric method) is much more specific, much more stable and more economical than that with the carbazole reagent which is generally used. Hence screening of the algae for their content of alginates can be done much more rapidly. 
TABLE 6.-Alginic acid in some species of Sargassum from various countries

\begin{tabular}{lcl}
\hline \multicolumn{1}{c}{ Species } & $\begin{array}{c}\text { Alginic acid } \\
(\% \text { dry wt.) }\end{array}$ & Country \\
\hline S. filipendula C. Agardh (6) ${ }^{1}$ & $13.3-23.5$ & U.S.A. \\
S. fluitans Børgesen (6) & 6.8 & U.S.A. \\
S. natans (L.) J. Meyen (6) & 9.0 & U.S.A. \\
S. longifolium J. Agardh (20) & 17.0 & Africa \\
S. polyceratium Montagne (7) & $13.9-20.0$ & Cuba \\
S. natans (L.) J. Meyen (7) & $15.2-16.0$ & Cuba \\
S. fluitans Børgesen (7) & $16.7-18.0$ & Cuba \\
S. swartzii (Turner) J. Agardh (17) & $4.5-14.7$ & India \\
S. tenerrimum J. Agardh (17) & $4.5-14.7$ & India \\
S. cinereum J. Agardh (17) & $29.1-$ & India \\
S. wightii Harvey (27) & $21.3-31.7$ & India \\
S. swartzii (Turner) J. Agardh (5) & $10.9-19.7$ & India \\
S. tenerrimum J. Agardh (5) & $7.1-11.2$ & India \\
S. wightii Harvey (26) & $29.8-34.6$ & India \\
S. tenerrimum J. Agardh (26) & $29.8-34.6$ & India \\
S. cymosum C. Agardh (21) & $8.5-19.4$ & Brazil \\
\hline
\end{tabular}

${ }^{1}$ Number in parentheses indicates corresponding reference.

\section{RESUMEN}

Se investigaron las variaciones estacionales en el contenido de ácido algínico en plantas completas, frondas y estipes de cuatro especies de Sargassum. Dos de las especies, S. polyceratium Montagne y S. vulgare J. Agardh, son sésiles; las otras dos, S. fluitans Borgesen y S. natans (L.) $J$. Meyen, son pelágicas. El contenido de ácido algínico en las especies sésiles varió en forma similar durante todo el año. Para ambas, las cantidades máximas de ácido algínico fueron registradas en mayo. Estos máximos fueron asociados con las fases reproductoras y vegetativas. Los valores más bajos de ácido algínico estuvieron asociados con la decadencia de las plantas después del proceso reproductivo. En las plantas completas, los rendimientos medios fueron de $20.3 \%$ y $17.9 \%$ en ácido algínico, en S. polyceratium y S. vulgare, respectivamente. Ambas especies arrojaron un contenido más alto de ácido algínico en los estipes que en las frondas. En S. fluitans el contenido de ácido algínico de los estipes fue más alto que en las frondas, mientras que en $S$. natans fue lo contrario. El rendimiento medio de ácido algínico en plantas completas de $S$. fluitans fue de $18.8 \%$ y en S. natans de $19.9 \%$.

\section{LITERATURE CITED}

1. Andersen, G., 1956. On the detection of alginic acid in tissues by means of birefringence. Proc. II Int. Symp. on Seaweeds, T. Braarud and N. A. Sørensen, Ed, Pergamon Press, London. 119-124.

2. Baardseth, E., 1966. Localization and structure of alginate gels. Proc. V Int. Symp. on Seaweeds, Halifax, N. S. 19-20. 
3. Baker, S. M., 1910. On the causes of zoning of brown seaweeds in the seashore. II. New Phytol. 9: 54-7.

4. Chapman, V. J., 1970. Seaweeds and their uses, Methuen \& Co., Ltd. 2nd ed.

5. Chauhan, V. D., 1970. Variation in alginic acid content with growth stages in two species of Sargassum, Bot. Mar. 13 (1): 57-8.

6. Davis, F. W., 1950. Algin from Sargassum, Science. 111: 50.

7. Diaz-Piferrer, M., 1961. Acido algínico en algunas especies de algas cubanas. I.C.I.T. 5 (1): 3-7. Habana, Cuba.

8. - - . 1979. Contribution and potentialities of Caribbean marine algae in pharmacology, In Marine algae in pharmaceutical science, H. A. Hoope, Levringe T. and Tanaka, Ed, W. de Gruyter, Berlin.

9. Earle, A. S., 1969. Phaeophyta of the Eastern Gulf of Mexico. Phycologia. 7 (2): $71-$ 254.

10. Frei, E. and Preston, R. D., 1962. Configuration of alginic acid in marine brown algae, Nature. 196: 130-34.

11. Graham, H. D., 1970. Specificity of the Ferric $-\mathrm{H}_{2} \mathrm{SO}_{4}$ reagent for alginates. J. Food Sci. 35:494-98.

12. Haug, A., 1958. Viscosity of alginate solutions, Proc. III. Int. Symp. on Seaweeds. Galway, Ireland.

13. - - 1961. The affinity of some divalent metals to different types of alginate, Acta Chem. Scand. 15 (8): 1794-795.

14. - - and Larsen, B., 1964. Studies on the composition and properties of alginates, Proc. IV Int. Symp. on Seaweeds, The MacMillan Co., London. pp 331-37.

15. Hellebust, J. A. and Haug, A., 1969. Alginic acid synthesis in Laminaria digitata (L.) Lamour, Proc. VI Int. Symp. on Seaweeds. pp. 463-71.

16. Hoyt, W. D., 1907. Periodicity in the production of sexual cells of Dictyota dichotoma. Notes from the Biological Laboratory. The John. Hopkins University Circular, No 195. Baltimore. pp 25-29.

17. Kappana, A. N., Rao, A. V. and Mody, I. C., 1962. Alginic acid content of some of the brown seaweeds of the Saurashtra coast. Curr. Sci. 31: 463-64.

18. Kreger, D. R., 1962. Cell Walls. In Physiology and Bio-chemistry of algae, R. A. Lewin, Ed, Academic Press Inc., New York. pp. 315-35.

19. Kylin, H., 1915. Untersuchungen über die biochemie des merealgen. Z. Physiol. Chem. Hoppe-Seyler's. 94: 337-425.

20. Ligthelm, S. P., Von Holdt, M. M. and Schumann, H. I., 1952. The composition of some South African Phaeophyceae. Proc. I Int. Seaweed Symp., Edinburgh.

21. Mandelli, M. Q., 1964. Sobre a composição química de algumas espécies de algas marinhas brasileiras. Cienc. Cult. São Paulo. 16: 281-84.

22. Mc Neely, W. H., 1959. Algin. In Industrial Gums, R. L. Whistler, Ed, Academic Press, New York, pp. 55-82.

23. Mody, I. C., Rao, A. V. and Dater, D. S., 1971a. Alginate from brown seaweeds of Saurashtra coast, Indian Chem. J. 6 (6): 31-2.

24. - - Rao, A. V. and Dater, D. S., 1971b. Alginic acid content in different parts of seaweeds, Indian Chem. J. 6 (6): 32-3.

25. Pillai, V. K., 1957. Alginic acid from Sargassum seaweeds, Res. \& Ind, 2: 70-1.

26. — - and Varier, N. S., 1953. Chemical analysis of seaweed of Tranvacore Cochin state. Proc. I Int. Seaweed Symp. Edinburgh, pp. 53-4.

27. Rao, M. U., 1969. Seasonal variations in growth, alginic acid and mannitol contents of Sargassum wightii and Turbinaria conoides from Gulf of Mannar, India. Proc. VI Int. Seaweed Symp. Ramón Margalef, Ed, Spain, pp. 579-84. 
28. Soloni, T. F. G., 1954. Ficocoloides de algas marinas cubanas. Contr. \# 4, Centro de Investigaciones Pesqueras. Habana, Cuba.

29. Stewart, W. D. P., 1974. Algal Physiology and Biochemistry, Bot. Monogr. Vol. 10, Blackwell Scientific Publications, London.

30. Taylor, W. R., 1960. Marine algae of the eastern tropical and subtropical coasts of the Americas, Univ. Mich. Press, Ann Arbor.

31. Wust, G., 1966. Stratification and circulation in the Antillean Caribbean basin, Part I. Vema Res. Series, 11. Columbia University Press. 